\title{
SLAUGYTOJŲ IR PACIENTŲ SOCIALINIŲ DEMOGRAFINIŲ VEIKSNIŲ BEI GYVENSENOS İTAKA SVEIKATOS MOKYMUI
}

\author{
Jovita Grudzinskienè $\dot{1}^{1}$, Rima Rozenbergaitè ${ }^{1}$, Rita Urbanavič $\check{e}^{1,2}$, Jonas Kairys ${ }^{1,2}$ \\ ${ }^{1}$ Vaiku ligonine, Vilniaus universiteto ligoninès Santaros kliniku filialas, \\ ${ }^{2}$ Vilniaus universiteto Medicinos fakulteto Sveikatos moksly institutas
}

Raktažodžiai: slaugytojai, sveika gyvensena, sveikatos mokymas.
Santrauka
Tyrimo tikslas - išanalizuoti slaugytojų ir pacientų so- cialinių demografinių veiksnių bei gyvensenos įtaką sveikatos mokymui. Tyrimui atlikti taikytas anketinès apklausos metodas. Tyrimas atliktas 2012-2013 me- tais viešosios ịstaigos Vilniaus universiteto ligoninès Santaros klinikų kardiologijos, vidaus ligų, endokri- nologijos, neurologijos, pulmonologijos, reumatolo- gijos skyriuose. Iš viso tyrime dalyvavo 282 respon- dentai, iš kurių 126 bendrosios praktikos slaugytojos ir 156 pacientai. Tyrimo medžiaga apdorota naudo- jantis IBM SPSS.20 statistikos paketu.
Slaugytojų amžius, išsilavinimas, darbo stažas, krūvis ar pobūdis (darbas dienomis ir budèjimai) reikšmin- gos ịtakos pacientų sveikos gyvensenos mokymui neturi. Skirtingo išsilavinimo pacientai, jų nuomone, gauna nevienodai sveikos gyvensenos informacijos: mažiausiai jos sulaukia aukštajị, daugiausia - vidurini išsilavinimą turintys pacientai $(\mathrm{p}=0,001)$. Slaugytojų psichoaktyviųjų medžiagų vartojimas neturejo ịtakos pacientų sveikatos mokymui. Pacientų gyvensena (rūkymas, alkoholio, migdomujų bei raminamujų vaistų vartojimas, viršsvoris) jų gaunamai sveikatos informacijai reikšmingos įtakos neturi.
Išvados. Slaugytojų amžius, išsilavinimas, darbo sta- žas, krūvis ir pobūdis, gyvensenos ypatumai (rūky- mas, alkoholio bei raminamujjų vartojimas) reikš- mingos įtakos pacientų sveikatos mokymui neturi. Pacientų išsilavinimas turi įtakos jų sveikatos moky- mui: mažiausiai informacijos sulaukia aukštajį, dau- giausia - vidurinị išsilavinimą turintys pacientai. $\mathrm{Pa}$ - cientų gyvensena (rūkymas, alkoholio ir raminamuju vartojimas) sveikatos mokymui įtakos neturi.

\section{Ivadas}

Sveikatos mokymas yra pagrindinè sveikatos stiprinimo priemonè. Jo tikslas - ugdyti elgesị, požiūrị ị vertybes, formuojančias ne tik individo, bet ir visos visuomenès sveikos gyvensenos pamatus. Pasaulio sveikatos organizacija sveikatos mokymą apibrèžia kaip sąmoningą žinių perdavimo veiklą, įskaitant kai kurias bendravimo formas, kurių tikslas - padidinti supratimą apie sveikatą, plètoti gyvensenos igūdžius, siejamus su asmens ir bendruomenès sveikata [1]. Sveikatos priežiūros ịstaigose vykdoma sveikatos mokymo ir švietimo veikla vadinama pacientų mokymu. Pacientų mokymas - tai kryptingos pastangos suteikti pacientams žinių, kaip apsisaugoti nuo ligų ir stiprinti sveikatą. Pacientas - tai asmuo, kuris naudojasi sveikatos priežiūros įstaigų teikiamomis paslaugomis, nesvarbu, ar jis sveikas, ar ligonis [2].

J. Marcum nurodo, kad pacientų mokymas yra dalis slaugytojų profesinès veiklos [3]. Daugelis užsienio autorių pažymi, kad bendravimas su pacientu, žinių apie slaugą, gydymą bei ligą suteikimas, sveikos gyvensenos mokymas turi didelès reikšmès pacientų pasitenkinimui ligoninès teikiamomis paslaugomis [4-6]. Mokslinių tyrimų ir edukacinių programų duomenimis, pacientų sveikatos mokymas pagerina ligų baigtis, trumpina gydymo laiką ligoninejje, mažina kartotinio hospitalizavimo būtinumą ir teikia galimybę daug efektyviau panaudoti sveikatos priežiūros išteklius.

Tyrimo tikslas - išanalizuoti slaugytojų ir pacientų socialinių demografinių veiksnių bei gyvensenos įtaką sveikatos mokymui.

\section{Tyrimo objektas ir metodika}

2012 metų lapkričio - 2013 metų kovo mènesị Vilniaus universiteto ligoninès Santaros klinikų kardiologijos, vidaus ligu, endokrinologijos, neurologijos, pulmonologijos, reumatologijos skyriuose buvo atliekama respondentų apklausa. Išdalinta 350 anketų, iš kurių 150 slaugytojoms ir 200 pacientams. Prieš tai buvo atliktas bandomasis tyrimas - ap- 
klausta 10 terapijos skyriaus slaugytojų ir 20 pacientų. Po apklausos klausimynai buvo pakoreguoti, tačiau jų esmè nepasikeitė. Kronbach alfa (Cronbach's alpha) koeficientas 0,72. Klausimynas - anketa

1 lentelè. Slaugytojų socialinės-demografinès charakteristikos ir suteiktos sveikatos informacijos ryšiai.

\begin{tabular}{|c|c|c|c|c|c|}
\hline & \multicolumn{3}{|c|}{$\begin{array}{c}\text { Informavimo dèl sveikatos balụ } \\
\text { vidurkis }\end{array}$} & $\begin{array}{l}\text { Statistinis } \\
\text { kriterijus }\end{array}$ & $\underset{p}{p}$ \\
\hline Amžius & $\begin{array}{c}18-30 \mathrm{~m} . \\
7,94\end{array}$ & $\begin{array}{c}30-45 \mathrm{~m} . \\
6,87\end{array}$ & $\begin{array}{c}46-65 \mathrm{~m} . \\
7,08\end{array}$ & $\begin{array}{l}\text { ANOVA } \\
(\mathrm{F}=0,663)\end{array}$ & 0,517 \\
\hline $\begin{array}{l}\text { Darbo } \\
\text { stažas }\end{array}$ & $\begin{array}{c}1-15 \mathrm{~m} . \\
6,57\end{array}$ & $\begin{array}{c}16-30 \mathrm{~m} . \\
7,04\end{array}$ & $\begin{array}{c}31-45 \mathrm{~m} . \\
7,46\end{array}$ & $\begin{array}{l}\text { ANOVA } \\
(\mathrm{F}=0,792)\end{array}$ & 0,455 \\
\hline $\begin{array}{l}\text { Išsilavi- } \\
\text { nimas }\end{array}$ & $\begin{array}{c}\text { aukštasis } \\
\text { universite- } \\
\text { tinis } \\
7,45\end{array}$ & $\begin{array}{c}\text { aukštasis } \\
\text { neuniver- } \\
\text { sitetinis } \\
6,78\end{array}$ & $\begin{array}{c}\text { aukštes- } \\
\text { nysis } \\
6,9\end{array}$ & $\begin{array}{c}\text { ANOVA } \\
(\mathrm{F}=0,436)\end{array}$ & 0,648 \\
\hline $\begin{array}{l}\text { Darbo } \\
\text { krūvis }\end{array}$ & $\begin{array}{c}0,25-0,5 \\
\text { etato } \\
8,00\end{array}$ & $\begin{array}{c}0,75-1,00 \\
\text { etato } \\
6,83\end{array}$ & $\begin{array}{c}1,25-1,5 \\
\text { etato } \\
6,97\end{array}$ & $\begin{array}{c}\text { ANOVA } \\
(\mathrm{F}=0,430)\end{array}$ & 0,651 \\
\hline $\begin{array}{l}\text { Darbo } \\
\text { pobūdis }\end{array}$ & $\begin{array}{c}\text { Visa darbo } \\
\text { diena } \\
6,81\end{array}$ & $\begin{array}{c}\text { budèjimai } \\
7,00\end{array}$ & $\begin{array}{c}\text { ne visa } \\
\text { darbo } \\
\text { diena } \\
-\end{array}$ & $\begin{array}{c}\text { Stjudento } t \\
(\mathrm{t}=0,337)\end{array}$ & 0,736 \\
\hline
\end{tabular}

2 lentelè. Slaugytojų psichotropinių medžiagų vartojimas ir jų teikiamos sveikatos informacijos ryšiai.

\begin{tabular}{|l|c|c|}
\hline \multirow{2}{*}{ Veiksnys } & \multicolumn{2}{|c|}{$\begin{array}{c}\text { Informavimo sveikatos klausimais balų } \\
\text { vidurkis }\end{array}$} \\
\hline \multirow{2}{*}{ Alkoholio vartojimas } & dažnai vartoja & retai/niekada \\
\cline { 2 - 3 } & 7,18 & 6,88 \\
\hline \multirow{2}{*}{ Rūkymas } & rūko & nerūko \\
\cline { 2 - 3 } & 7,57 & 6,76 \\
\hline \multirow{2}{*}{ Vaistų vartojimas } & vartojo & nevartojo \\
\cline { 2 - 3 } & 7,14 & 6,86 \\
\hline
\end{tabular}

3 lentelè. Pacientų socialinių-demografinių veiksnių ir gaunamos sveikatos informacijos ryšiai.

\begin{tabular}{|c|c|c|c|c|c|c|}
\hline Veiksnys & \multicolumn{4}{|c|}{$\begin{array}{l}\text { Sveikatos informacijos kokybės } \\
\text { balų vidurkis }\end{array}$} & $\begin{array}{l}\text { Statistinis } \\
\text { kriterijus }\end{array}$ & $\underset{\text { reikšmé }}{\mathbf{p}}$ \\
\hline Lytis & \multicolumn{2}{|c|}{$\begin{array}{c}\text { moterys } \\
3,47\end{array}$} & \multicolumn{2}{|c|}{$\begin{array}{c}\text { vyrai } \\
4,16\end{array}$} & $\begin{array}{c}\text { Mann- } \\
\text { Whitney } \\
(\mathrm{U}=3284,0)\end{array}$ & 0,272 \\
\hline Amžius & $\begin{array}{c}18-40 \mathrm{~m} . \\
2,5\end{array}$ & \multicolumn{2}{|c|}{$\begin{array}{l}41-60 \mathrm{~m} \\
3,75\end{array}$} & $\begin{array}{c}61-89 \mathrm{~m} . \\
4,29\end{array}$ & $\begin{array}{c}\text { Kruskal- } \\
\text { Wallis } \\
(\mathrm{H}=4,792)\end{array}$ & 0,091 \\
\hline $\begin{array}{l}\text { Išsilavi- } \\
\text { nimas }\end{array}$ & $\begin{array}{c}\text { pagrindi- } \\
\text { nis } \\
4,17\end{array}$ & $\begin{array}{l}\text { vidu- } \\
\text { rinis } \\
\mathbf{5 , 3 9}\end{array}$ & $\begin{array}{c}\text { aukš- } \\
\text { tesnysis } \\
4,02\end{array}$ & $\begin{array}{c}\text { aukštasis } \\
\mathbf{2 , 7 0}\end{array}$ & $\begin{array}{c}\text { Kruskal- } \\
\text { Wallis } \\
(\mathrm{H}=11,730)\end{array}$ & 0,008 \\
\hline $\begin{array}{l}\text { Gyvenimo } \\
\text { vieta }\end{array}$ & \multicolumn{2}{|c|}{$\begin{array}{c}\text { miestas } \\
3,76\end{array}$} & \multicolumn{2}{|c|}{$\begin{array}{c}\text { kaimas } \\
3,87\end{array}$} & $\begin{array}{c}\text { Mann- } \\
\text { Whitney } \\
(\mathrm{U}=1854,5)\end{array}$ & 0,898 \\
\hline
\end{tabular}

sudaryta remiantis surinkta moksline literatūra.

Gautieji duomenys buvo tvarkomi naudojantis IBM SPSS.20 statistikos paketu. Slaugytojų ir pacientų požiūrio ị sveikatos mokymą (nuomonès apie sveikatos mokymo svarbą, žinių apie gyvensenos įtaką ligai) palyginimui, duomenys aprašyti dažnių lentelèse. Hipotezių patikrinimui taikytas chi kvadrato (chi-square) kriterijus $\left(\chi^{2}\right)$. Slaugytojų ir pacientų sveikatos mokymo žinių vertinimo palyginimui taikytas Student $t$ kriterijus nepriklausomoms imtims.

Slaugytojams ir pacientams buvo užduota 12 klausimų, ar jie buvo informuoti įvairiais sveikatos klausimais. Atsakymai į šiuos klausimus buvo pakeisti balais: „taip“- 1 balas, „ne“ -0 balų, ,tik paklausus" - 0,5 balo. Balai buvo sumuojami, galima didžiausia balų suma -12 . Didesnis balas reiškia, kad slaugytojai pacientams suteikia daugiau sveikatos informacijos. Taip pertvarkytus tyrimo dalyvių atsakymus buvo galima apibendrinti ir palyginti slaugytojų teikiamą ir pacientų gaunamą informaciją. Priklausomai nuo gauto kintamojo atitikties normalumo kriterijaus, pacientu ir slaugytojų amžiaus, išsilavinimo, lyties, atsakymų ir kitų ịverčių palyginimui taikytas Stjudento $t$ kriterijus ir vieno faktoriaus dispersinè analizė (ANOVA) arba jų neparametriniai atitikmenys - Mann-Whitney ir Kruskal-Wallis kriterijai.

Statistinis reikšmingumas lyginant tiriamųjų grupes, žymimas $p$ reikšme. Duomenys laikytini statistiškai reikšmingi, jei $p$ reikšmė $<0,05$. Jei $p$ reikšmé lygi ar didesnè už 0,05 , duomenys nelaikytini statistiškai reikšmingais ir pasikliaujama apskaičiuotu skirtumu.

\section{Tyrimo rezultatai}

Slaugytojų socialinès demografinès charakteristikos ir sveikos gyvensenos mokymo sąsajos pateikiamos 1 lentelèje. Slaugytojų, dirbančių ne visą darbo dieną, nebuvo.

Sveikatos informacijos analizè tarp skirtingų lyčių slaugytojų nebuvo atliekama, nes tyrime dalyvavo vien moterys slaugytojos.

Slaugytojų psichotropinių medžiagų (rūkymo, alkoholio, migdomųjų bei raminamųjų) vartojimo ir informavimo sveikos gyvensenos klausimais sąsajos. Pagal alkoholio vartojimą slaugytojos suskirstytos i dvi grupes: pirmoji grupe vartojančios alkoholį 2-4 kartus per savaitę ir 2-4 kartus per mènesį; antroji - retai arba niekada nevar- 
tojančios alkoholio (vartoja 1 kartą per mėnesị ir rečiau, arba nevartoja). Taip suskirsčius, 24 slaugytojos pateko ị alkoholi vartojančių (19,8 proc.) ir 101 - i retai arba niekada nevartojančiujų grupę (80,2 proc.). Pritaikius Stjudento $t$ kriterijų, nustatyta, kad alkoholį ir dažnai, ir retai vartojančios, arba jo niekada nevartojančios slaugytojos pacientus sveikatos klausimais informuoja vienodai $(\mathrm{t}=0,497, \mathrm{p}=0,62)$. Rūkančių ir nerūkančių $(\mathrm{t}=1,433, \mathrm{p}=0,155)$, vaistus vartojančių ir nevartojančių $(t=0,519, p=0,605)$ slaugytojų, pacientų informavimas sveikatos klausimais taip pat nesiskyrè. Rezultatai pateikiami 2 lenteleje.

Pacientų socialinių demografinių veiksnių ir gaunamos informacijos skirstinių tikrinimo rezultatai pateikiami 3 lenteleje. Nesant galimybès atlikti vienfaktorinès dispersinès analizès ANOVA (pacientų imtyje sveikatos informavimo kokybės kintamasis neatitiko normalumo kriterijų), sveika-

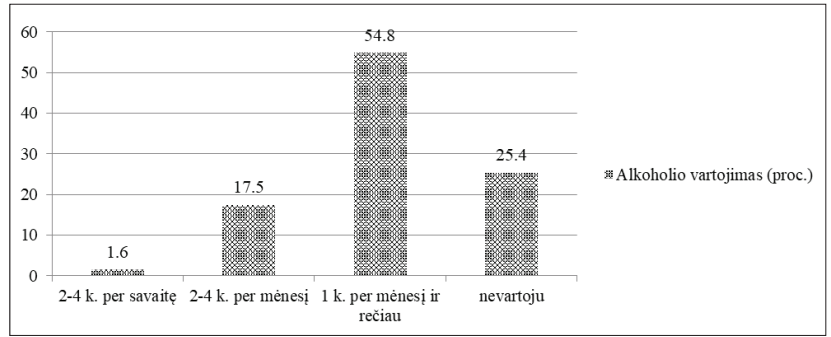

1 pav. Pacientų alkoholio vartojimo dažnis.

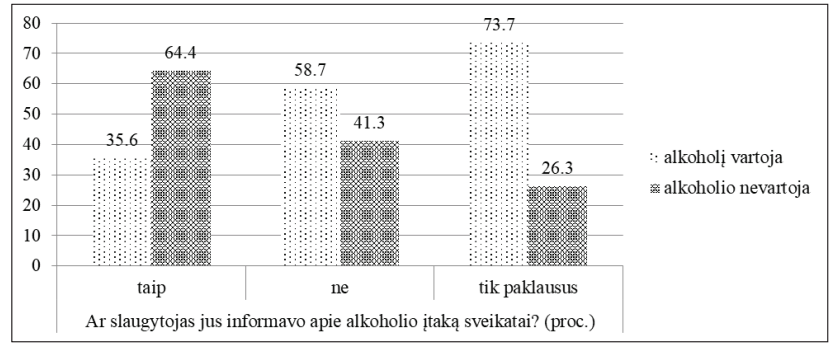

2 pav. Pacientu alkoholio vartojimo ir informavimo apie alkoholio poveikị sveikatai dažnis.

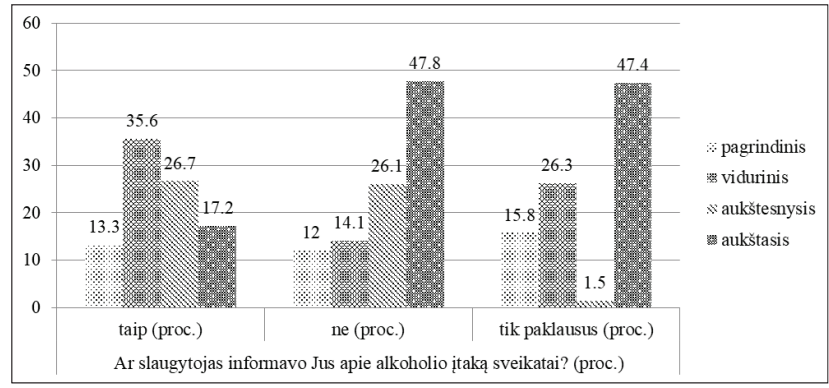

3 pav. Pacientų išsilavinimas ir gautos informacijos apie alkoholio poveikį sveikatai dažnis. tos informavimo kokybès balų vidurkiu palyginimui taikyti neparametriniai statistiniai kriterijai (3 lentelè).

Pastebèta, kad skirtingo išsilavinimo pacientai, jų nuomone, nevienodai gauna sveikos gyvensenos informacijos. 3 lenteleje pateikti duomenys parode, kad mažiausiai informacijos sulaukia aukštajị, daugiausia - vidurinį išsilavinimą turintys pacientai. Šis pastebejimas patikrintas taikant Mann-Whitney kriterijų. Nustatyta, kad apklaustieji pacien-

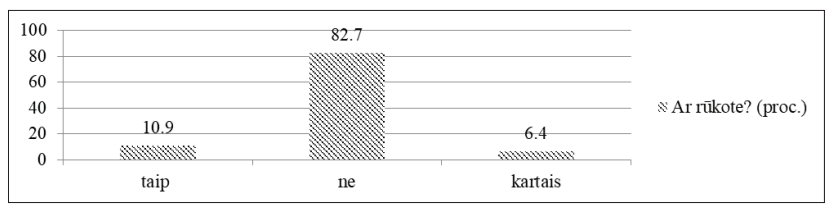

4 pav. Pacientų rūkymo dažnis.

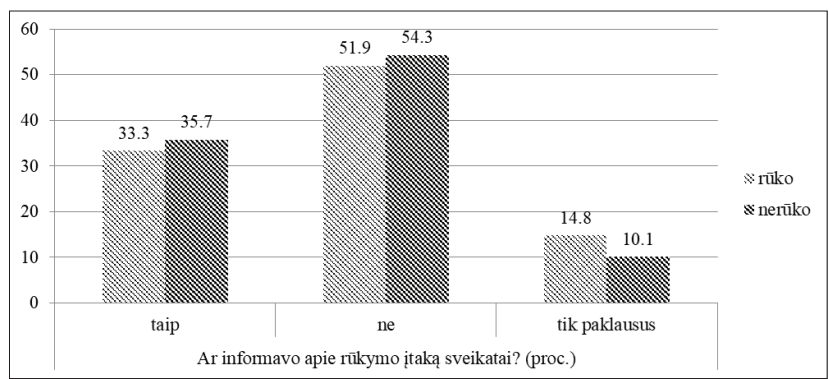

5 pav. Rūkymo ir informavimo apie rūkymo poveikị sveikatai dažniai.

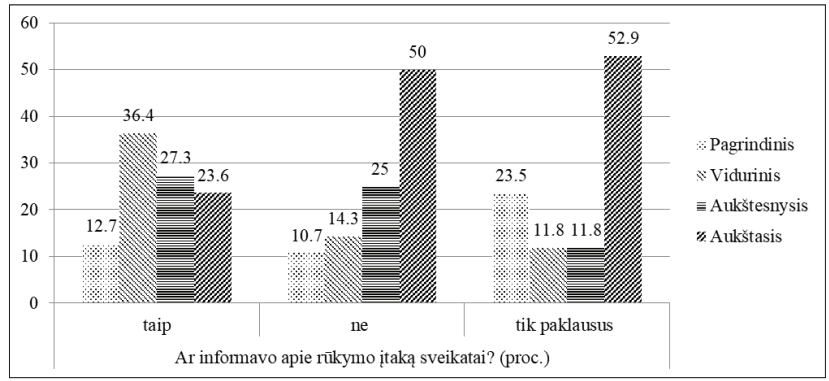

6 pav. Išsilavinimas ir informavimo apie rūkymo poveikị sveikatai dažnis.

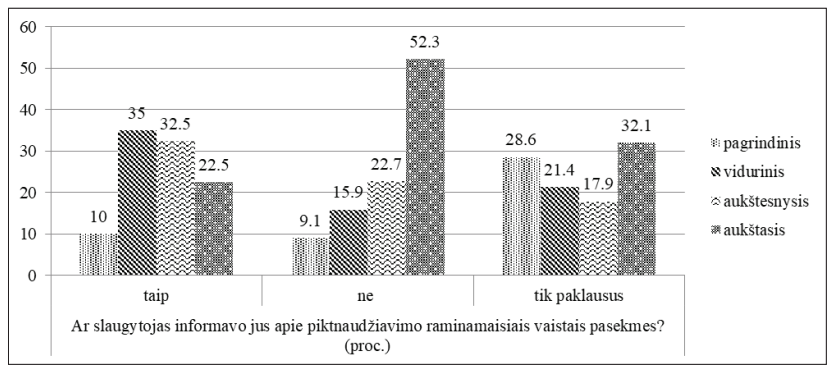

7 pav. Pacientų išsilavinimas ir informavimo apie piktnaudžiavimo raminamaisiais vaistais poveiki dažniai. 
tai, turintieji vidurinị išsilavinimą, išties sulaukè daugiau ir dažniau sveikos gyvensenos informacijos, nei turintieji aukštajji išsilavinimą ( $U=626,0, p=0,001)$.

Pacientų alkoholio vartojimas. 2-4 kartus per savaitę alkoholi vartoja 2 apklausti pacientai, 2-4 kartus per mėnesi $-22,1$ kartą per mènesị ir rečiau - 69 pacientai. Alkoholio nevartoja 32 apklausti pacientai (1 pav.).

Pacientų alkoholio vartojimas ir informavimas apie alkoholio poveikị sveikatai. Tirta, ar alkoholị vartojantys pacientai sulaukè informacijos apie alkoholio poveikị sveikatai. Tam tikslui pacientai buvo suskirstyti ị dvi grupes - alkoholị vartojančius (nesvarbu, kaip dažnai) ir nevartojančius. Rezultatai pateikiami 2 paveiksle.

Rezultatai parodè, kad apie alkoholio poveikị sveikatai buvo informuoti net 64,4 proc. alkoholio nevartojančių pacientų. Apie alkoholio poveiki ,tik paklausus“, buvo informuoti net 73,7 proc. alkoholi vartojančiu ir 26,3 proc. nevartojančių pacientu $\left(\chi^{2}=9,937, \mathrm{p}=0,007\right)$.

Apibendrinant rezultatus galima teigti, kad alkoholio vartojimas neturi didelès įtakos pacientų informavimui apie alkoholio poveiki sveikatai. Daugiau informacijos sulaukè alkoholi vartojantys pacientai, patys paklausę slaugytojų apie alkoholio žalą sveikatai.

Pacientų demografinè charakteristika ir informavimas apie alkoholio poveikị sveikatai. Tirta, ar skirtingos lyties, amžiaus ir išsilavinimo pacientai panašiai dažnai sulauke informacijos apie alkoholio poveikị sveikatai. Pritaikius chi kvadrato kriterijų, paaiškejjo, kad informacija apie alkoholio poveikị sveikatai vyrams ir moterims teikiama panašiu dažnumu $\left(\chi^{2}=4,465, p=0,107\right)$; ivvairaus amžiaus pacientams teikiamos informacijos dažnis nesiskiria $\left(\chi^{2}=4,834, p=0,305\right)$; šis dažnis nesiskiria gyvenantiems kaime ir mieste $\left(\chi^{2}=1,748\right.$, $\mathrm{p}=0,417)$. Rasti skirtumai tarp skirtingo išsilavinimo pacientu $\left(\chi^{2}=12,704, p=0,048\right)$. Rezultatai apie pacientų išsilavinimą ir informavimą apie alkoholio poveikị sveikatai pateikiami 3 paveiksle.

Tyrimo duomenys parode ( 3 pav.), kad apie alkoholio poveikị sveikatai mažiausiai informuojami įgijusieji aukštaji išsilavinimą ( 47,8 proc.). Tokių yra daugiausia ir tarp pacientų, kuriems informacija buvo suteikta „tik paklausus“ (47,4 proc.).

Pacientų rūkymas ir gaunamos informacijos apie rūkymo poveikị sveikatai dažnis. Buvo tiriamas pacientų rūkymo dažnis. Tyrimo rezultatai atskleidè, kad 17 pacientų rūko, 10 - kartais rūko, 129 - nerūko. Apklaustų pacientų rūkymo dažnis parodytas 4 paveiksle.

Tirta, ar rūkantys pacientai gauna informacijos apie rūkymo poveikị sveikatai. Tyrime dalyvavę pacientai buvo suskirstyti ị dvi grupes: rūkantieji (rūko, kartais rūko) ir nerūkantieji. Pritaikius chi kvadrato kriterijų paaiškejjo, kad rūkantieji ir nerūkantieji buvo panašiai informuoti apie rūkymo poveiki sveikatai $\left(\chi^{2}=0,518, \mathrm{p}=0,772\right)$. Rezultatai pateikiami 5 paveiksle.

5 paveiksle parodyta, kad apie rūkymo poveikị sveikatai informuota 33,5 proc. rūkančiu ir 35,7 proc. nerūkančių pacientų. Neinformuotų ir informacijos sulaukusių „tik paklausus“, rūkančių ir nerūkančių pacientų dalis buvo panaši.

Pacientų demografinè charakteristika ir informavimas apie rūkymo poveikị sveikatai. Pacientų lytis $\left(\chi^{2}=4,051, p=0,132\right)$, gyvenimo vieta $\left(\chi^{2}=4,596, p=0,1\right)$, amžius $\left(\chi^{2}=4,348, p=0,361\right)$ nesusiję su informavimu apie rūkymo ịtaką sveikatai, bet skirtingo išsilavinimo respondentai buvo informuoti skirtingai $\left(\chi^{2}=17,730, p=0,007\right)$. Rezultatai pateikiami 6 paveiksle.

Kaip ir informavimo apie alkoholio poveikị sveikatai atveju, labiausiai išsilavinę pacientai, palyginti su žemesnio išsilavinimo, daug dažniau informacijos apie rūkymo poveikị sveikatai negaudavo, arba jos sulaukdavo tik paklausę.

Tyrimo rezultatai parode, kad raminamujų ir (ar) migdomujų vaistų vartojimas yra opi problema: didesnè dalis apklaustų pacientų (57,1 proc.) vartoja šiuos vaistus ir gydytojo paskirtus, ir nesant gydytojo paskyrimo.

Analizuota, ar vaistus vartojantys pacientai sulaukia informacijos apie piktnaudžiavimo migdomaisiais ir (ar) raminamaisiais vaistais poveikị sveikatai. Tyrime dalyvavę pacientai buvo suskirstyti ị dvi grupes: vartojusius šiuos vaistus per pastaruosius 12 mėnesių (vartojo nesant gydytojo paskyrimo, gydytojui paskyrus ar abiem atvejais) ir nevartojusius.

Pacientų demografinė charakteristika ir jų informavimas apie piktnaudžiavimo raminamaisiais vaistais poveiki. Pacientu lytis $\left(\chi^{2}=0,930, p=0,628\right)$, gyvenimo vieta $\left(\chi^{2}=0,886, p=0,642\right)$, amžius $\left(\chi^{2}=6,432, p=0,169\right)$ nesusiję su informavimu apie piktnaudžiavimo raminamaisiais vaistais poveikị, tačiau skirtingo išsilavinimo respondentai šios informacijos sulaukè skirtingu dažniu $\left(\chi^{2}=19,491, p=0,003\right)$. Rezultatai pateikiami 7 paveiksle.

7 paveiksle parodyta, kad rečiausiai apie piktnaudžiavimo vaistais poveikị informuojami pagrindinị išsilavinimą turintieji asmenys (tik 10 proc.), o dažniausiai - turintieji vidurinị išsilavinimą (35 proc.). Dažniausiai slaugytojos neinformavo aukštajj̨ išsilavinimą turinčių (52,3 proc.) pacientų, palyginti su 22,7 proc. aukštesnijj išsilavinimą igijusių, 15,9 proc. vidurinị išsilavinimą turinčių neinformuotų pacientų.

\section{Rezultatu aptarimas}

Ištyrus slaugytojų socialinès-demografinès charakteristikos ir jų teikiamos sveikatos informacijos ryšius, nustatyta, kad nei slaugytojų amžius, nei išsilavinimas, nei darbo stažas, krūvis ar pobūdis (darbas dienomis ar budejjimai) 
reikšmingos įtakos pacientų sveikos gyvensenos mokymui neturi. Galima manyti, kad visos slaugytojos, nepriklausomai nuo jų amžiaus, išsilavinimo bei darbo sąlygų, vienodai stengiasi mokyti pacientus sveikos gyvensenos. Šio tyrimo duomenys nesutapo su D. Zagurskienès, I. Misevičienès [7] ir V. Račkauskaitės [8] tyrimų rezultatais. Autorių teigimu, jų apklausti slaugytojai, turintys aukštaji išsilavinimą, buvo savikritiškesni ir dažniau prisipažino pakankamai nesuteikiantys informacijos pacientams [7,8].

Lietuvoje atliktų mokslinių tyrimų duomenimis [7-10], pacientų nuomonė apie slaugytojų informacijos teikimą priklausè nuo pacientu amžiaus, lyties, gyvenamosios vietos bei išsilavinimo: sveikatos informacijai reiklesni jaunesni, iki 45 metų, miesto gyventojai, igiję aukštajj išsilavinimą pacientai, dažniau - moterys. Šiame tyrime buvo ieškoma ryšio tarp pacientų amžiaus, lyties, gyvenamosios vietos, išsilavinimo ir suteiktos sveikos gyvensenos informacijos. Nustatyta, kad skirtingą išsilavinimą turintys pacientai, jų nuomone, gauna nevienodai sveikos gyvensenos informacijos: mažiausiai jos sulaukia aukštaji, daugiausia - vidurini išsilavinimą turintys pacientai $(\mathrm{p}=0,001)$. Galima daryti prielaidą, kad slaugytojos gali manyti, jog aukštaji išsilavinimą turintiems pacientams pakanka sveikos gyvensenos žinių, todèl juos rečiau informuoja.

Vis didesne problema pasaulyje tampa psichoaktyviujų medžiagų vartojimas $[11,12]$. Tabako, alkoholio vartojimas turi socialinių ir sveikatos pasekmių. Nustatyti priežastiniai ryšiai tarp vidutinio suvartoto alkoholio kiekio ir daugiau nei 60 ligų [13, 14]. Vartojant migdomuosius ar raminamuosius vaistus, greitai atsiranda tolerancija, psichologinè ir fizinè priklausomybè. Ilgiau vartojant, atsiranda gili depresija, stiprūs atminties sutrikimai [15].

Šiame tyrime nagrinejjant slaugytojų gyvensenos (rūkymo, alkoholio ir migdomujų ar raminamujų vaistų) įtaką pacientų informavimui sveikos gyvensenos klausimais nustatyta, kad alkoholị dažnai vartojančių ir niekada (retai) nevartojančių, rūkančių ir nerūkančių, raminamuosius per pastaruosius 12 ménesių vartojusių ir nevartojusių slaugytoju informavimas sveikatos klausimais nesiskiria. Slaugytoju psichoaktyviujjų medžiagų vartojimas neturejo įtakos pacientų sveikatos mokymui.

Tirta, ar rūkantys, vartojantys alkoholị ir migdomuosius ar raminamuosius pacientai buvo dažniau informuojami apie psichoaktyviưjų medžiagų žalą, nei jų nevartojantys. Šio tyrimo metu nustatyta, kad pacientų gyvensena (rūkymas, alkoholio, migdomujų ar raminamujų vartojimas, antsvoris) jų gaunamai sveikatos informacijai reikšmingos įtakos neturi. Gauti rezultatai parodé, kad, pavyzdžiui, rūkantieji pacientai, palyginti su nerūkančiaisiais, nebuvo dažniau informuojami apie rūkymo žalą sveikatai. Galima manyti, kad slaugytojai neigudę padėti pacientams spręsti su jų gyvensena susijusių problemų.

\section{Išvados}

Slaugytojų amžius, išsilavinimas, darbo stažas, krūvis ir pobūdis bei gyvensenos ypatumai (rūkymas, alkoholio bei raminamujų vartojimas) reikšmingos įtakos pacientų sveikatos mokymui neturi. Pacientų išsilavinimas turi įtakos jų sveikatos mokymui: mažiausiai informacijos sulaukia aukštajị, daugiausia - vidurinị išsilavinimą turintys pacientai. Pacientų gyvensena (rūkymas, alkoholio ir raminamųu vartojimas) jų sveikatos mokymui įtakos neturi.

\section{Literatūra}

1. Nutbeam D. Health promotion glossary. Health Promotion International 1998;13(4):349-364. https://doi.org/10.1093/heapro/13.4.349

2. Lietuvos standartas LST 1452:1997 Sveikata. Terminai ir apibrèžimai, 1997;1452.

3. Marcum J, Ridenour M, Schaff G, Hammons M, Taylor M. A study on professional nurses' perceptions of patients education. J Contin Educ Nurs 2002;33(3):112-118 https://doi.org/10.3928/0022-0124-20020501-05

4. Merkowis A, Ifatopaulos J, Lanara V. Patient satisfaction: a key for evaluating and improving nursing services. J Nurs Manag 1999;7:19-28. https://doi.org/10.1046/j.1365-2834.1999.00101.x

5. Ellers B. Innovation in patient-centered education. In: Gerteis M, Edgman-Levitan S, Daley J, Delbanco TL, editors. Through the patient's eyes.1st ed. San Francisco: Josseu-Bass Publisher 1993;96-118.

6. Fallowfield L, Jenkins V. Effective communication skills are the key to good cancer care. Eur J Cancer 1999;35:1592-7. https://doi.org/10.1016/S0959-8049(99)00212-9

7. Zagurskienė D., Misevičienė I. Pacientų ir slaugytojų nuomonės apie sveikatos mokymą ir slaugytojų dalyvavimą šiame procese palyginimas. Medicina, 2008;44(11):885-894.

https://doi.org/10.3390/medicina44110112

8. Račkauskaitė V. Slaugytojų veikla ugdant pacientų sveiką gyvenseną. Magistro darbas, Kauno medicinos universitetas. Kaunas, 2009;38-81.

9. Bučiūnienè I., Petkinis J., Milašauskienė Ž. Ligoninès medicinos personalo ir pacientų vertinimai apie medikų ligoninèje teikiamas paslaugas. Medicina, 2004;40(3):272-7.

10. Misevičienė I., Milašauskienė Ž. Pacientų pasitenkinimas ligoninès medicinos personalo darbu. Medicina, 2002; 38(5):559-565.

11. Metinis pranešimas 2010. Narkotikų kontrolès departamentas prie Lietuvos Respublikos Vyriausybès. Vilnius, 2010. http:// www.Nkd.1t/files/informacinemedzega/1-NKD_medziaga/1metiniaipranesimai/ 2010metinispranesimas.pdf. 
12. Narkotikų problema Europoje. 2010 m. metinè ataskaita. Europos narkotikų ir narkomanijos stebėsenos centras. Liuksemburgas, 2010. http://www.emcdda.europa.eu/ publications/annual-report/2010. http:/www.Nkd.lt/files/ informacinemedzega/1-NKD medziaga/1-metiniaipranesimai/ 2010metinispranesimas.pdf.

13. Reducing Risks, Promoting Healthy Life. The World Health Report 2002. WHO, 2002. http://www.who.int/whr/ 2002/en/ whr02en.pdf.

14. European cardiovascular disease statistics. University of Oxford, 2005. http://www.msps.es/organizacion/sns/planCalidadSNS/pdf/ excelencia/cancer-cardiopatia/CARDIOPATIA/ opscest3.pdf.pdf.

15. Astrauskienė A., Abaravičius A., Bartkevičiūtė R., Barzda A., Bulotaitė L., Klumbienè J., Petkevičienè J., Stukas R. Sveikos gyvensenos rekomendacijos. Metodinès rekomendacijos. Mokomoji knyga. Vilnius, 2011.

\section{THE INFLUENCE OF SOCIO-DEMOGRAPHIC CHARACTERISTICS AND LIFESTYLES OF NURSES AND PATIENTS ON HEALTH EDUCATION}

J.Grudzinskienė, R.Rozenbergaitė, R.Urbanavičè, J.Kairys

Keywords: nurses, healthy lifestyle, health education.

Summary

The research aim was to analyse the impact of socio-demographic factors and lifestyles of nurses and patients on health education. The study used a questionnaire survey. The research was conducted at the departments of Cardiology, Internal Diseases, Endocrinology, Neurology, Pulmonology and Rheumatology of the teaching hospital Vilnius University Hospital Santaros Clinics in 2012-2013. The survey involved 282 respondents including 126 nurses responsible for general care and 156 patients. The research results were processed using IBM SPSS.20 statistical soft- ware package.

The age, the level of education and training and the length of service, the workload and the nature of job (day and night shift) of the nurses does not have significant influence on the teaching of patients about healthy lifestyle habits. In their view, patients with different educational background receive varying levels of information on the issues of healthy lifestyles: the least information is provided to the patients with a tertiary level of education while the patients with a secondary level of education obtain the highest amount of information $(\mathrm{p}=0,001)$. The use of psychoactive substances by the nurses did not have impact on how the surveyed nurses provided information on health issues to their patients. The lifestyles of the patients (smoking, the use of alcohol, sedative/hypnotic drugs, and overweight) do not have significant influence on health information received by them.

Conclusions: The age, the level of education and training, the length of employment, the workload and the nature of job, and lifestyle behaviours (smoking, the use of alcohol and sedatives) does not demonstrate any significant impact on the patient education. The patients' educational background does have an impact on their health education: the patients with a tertiary level of education receive the least information while those with a secondary level of education receive the highest amount of information. The patients' lifestyles (smoking, the use of alcohol and sedatives) do not influence their health education.

Correspondence to: jovita.grudzinskiene@santa.It

Gauta 2019-10-23 